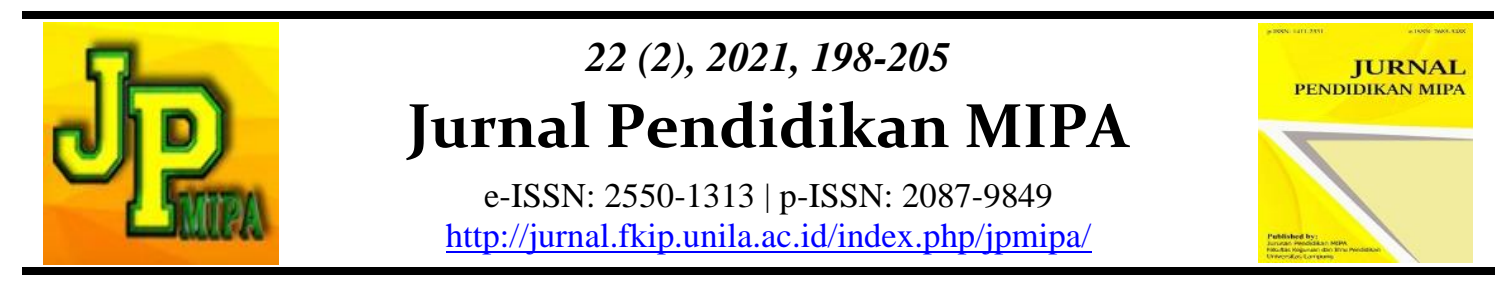

\title{
Assessing the Acceptance of Blended Learning Implementation in Universitas Lancang Kuning using the Technology Acceptance Model
}

\author{
Rizki Novendra $^{1}$, Ambiyar $^{2}$, Fadhilah $^{2}$, Syahril $^{2}$, Sutejo $^{2}$, Yogi Ersan Fadrial ${ }^{2}$ \\ ${ }^{1}$ Faculty of Computer Science, Universitas Lancang Kuning, Indonesia \\ ${ }^{2}$ Technology and Vocational Education, Universitas Negeri Padang, Indonesia
}

\begin{abstract}
The Covid-19 pandemic has forced learning activities to be carried out online. In response to this, Universitas Lancang Kuning, which has implemented the Blended Learning application, wants to measure the level of use and understand the factors that influence the acceptance of the system in an agency. The study was conducted at the Unilak Fasilkom with 92 samples. Data obtained by distributing questionnaires based on indicators and variables of the technology acceptance modelling method. The results of this study indicate that the multiple regression analysis of the variables that have an influence on the real condition of information users is the variable Benefits of using information systems (X1), User Ease of Information Systems (X2), and User Attitudes towards Information Systems (X3) have a significant influence on real condition of information system users (Y). Meanwhile, the behavior of information system users (X4) has no effect
\end{abstract}

Keywords: technology acceptance model, blended learning, covid-19 pandemic.

Abstrak: Pandemi Covid - 19 memaksa kegiatan belajar untuk dilaksanakan secara daring. Menanggapi hal tersebut Universitas Lancang Kuning yang telah menerapkan aplikasi pembelajaran Blendeed Learning ingin melakukan pengukuran terhadap tingkat penggunaannya dan memahami faktor-faktor yang mempengaruhi di terimanya sistem pada suatu instansi. Penelitian dilaksanakan pada Fasilkom Unilak dengan 92 sampel. Data diperoleh dengan menyebarkan angket yang berdasarkan indicator serta variable dari metode technology acceptance modelling. Hasil dari penelitian ini menyaakan bahwa analisis regreasi berganda variabel yang memiliki pengaruh terhadap kondisi nyata pengguna informasi adalah variabel Manfaat penggunaan sistem informasi (X1), Kemudahan Pengguna Sistem Informasi (X2), dan Sikap Pengguna Terhadap Sistem Informasi (X3) memiliki pengaruh yang signifikan terhadap kondisi nyata pengguna sistem informasi $(Y)$. Sedangkan perilaku pengguna sistem informasi (X4) tidak memiliki pengaruh.

Kata kunci: technology acceptance model, blended learning, TAM, pandemic covid-19.

\section{- INTRODUCTION}

The development of the times has been in the era of the industrial revolution 4.0. Where information system technology has developed rapidly and triggered changes in terms of innovation in various fields, including the field of Education (Darma et al., 2020). During this Covid-19 pandemic, students and lecturers carry out online or remote teaching and learning processes without having to face to face in class. Online lectures are carried out as an effort to break the chain of the spread of the virus. The Blended Learning model is one solution for the implementation of lectures during the pandemic,

Rizki Novendra et al.

Email: rizkinovendra@unilak.ac.id
DOI: http://dx.doi.org/10.23960/jpmipa/v22i2.pp198-205

Received: 29 November 2021

Accepted: 29 December 2021 
which with Blended Learning can combine LMS and virtual face-to-face (Setiawan \& Aden, 2020).

Lancang Kuning University has utilized a learning application, namely Unilak Blended Learning. According to data from the Center for Information Technology and Learning, Lancang Kuning University (PTIP) in the document of the results of monitoring and evaluation of learning using the Blended Learning application. The use of blended learning applications is still relatively low. It is not known what factors influence the low use of blended learning. Monitoring and evaluation was carried out on 1,252 courses with assessment components including semester learning plans (RPS), lecture implementation times, student assignments, learning materials and media, UTs, UAS, discussion rooms/feedback forms, question banks and total final scores.

Activities Utilization of information system technology, it is necessary to measure the level of use and understand the factors that influence the acceptance of the system in an agency. One of the methods used to measure using the Technology Acceptance Model (TAM). To find out the extent to which the application of the Unilak Blended Learning Information System application online at Lancang Kuning University. This measurement will be directly related to user satisfaction. One of the users is a student. In this study, the object of research which is centered on Fasilkom Unilak students is active and has used the Unilak Blended Learning account. Researchers took a sample of 92 respondents from Fasilkom Unilak students.

There are several studies that discuss the application of Blended Learning which is the reference of this research. One of them is research Flourensia Sapty Rahayu, Djoko Budiyanto , David Palyama (2017) conduct research on the acceptance of an e-learning using the TAM method. Here they argue that the implementation of an information system cannot be said to be successful, if it has not been measured from the user's side. The test was conducted to find out the effect of e learning with the help of the TAM variable. Statistical tests were carried out and resulted in the acceptance of five hypotheses and one being rejected. Although users have understood and felt the benefits of e-learning, it did not affect their interest in using the system. This can happen because even though a user feels that the use of e-learning will help him in completing academic matters, but because the use of e-learning is mandatory, it causes them to have no interest in continuing to use it. (Rahayu et al., 2017).

From the use of Blended Learning, not all students who use learning applications successfully use it perfectly. Some students have experienced problems in using the application, and the understanding of the use of Blended Learning is still not maximal. Then it will have an impact on student learning activities on Blended Learning itself. So that later, the application of Blended Learning will not achieve the target as desired by the facilitator in the learning and teaching process. The results of measuring user satisfaction, will be used to develop and improve information system services using the Unilak Blended Learning application.

\section{- METHOD}

As previously mentioned, this study discusses the acceptance of Blended Learning technology from the user's side. The research was conducted at the Unilak Fasilkom. There are 1,193 students from two Informatics Engineering and Information Systems study programs. Based on the total population, 92 samples were obtained using the Slovin formula. From the total sample, a questionnaire was distributed with the aim of obtaining research data. The Technology Acceptance Modeling (TAM) model is used in this study, 
with several variables in it helping the process of analyzing what factors affect the acceptance of a technology. (Nerisafitra \& Susanto, 2019).

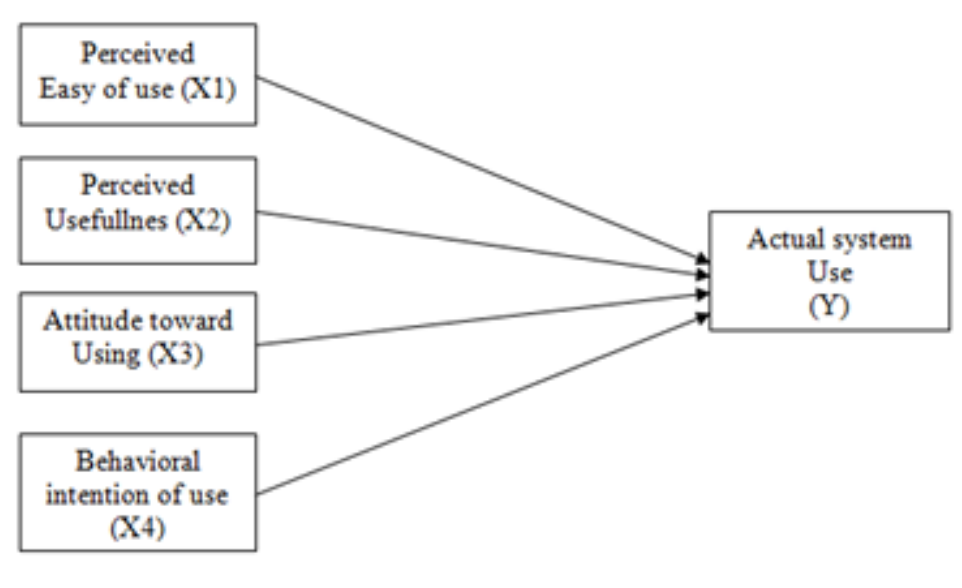

Figure 1. Technology Acceptance Model (TAM)

There are several variables in TAM method, The following is an explanation of the variables used in the Technology Acceptance Models (TAM) method Ease of use (Ease of use): Ensuring that information technology will be easy to use, Usefulness: ensuring that the information technology used will provide benefits, Attitude towards using: convincing the attitude of users to use the information technology, Behavioral intention of use: increasing user behavior to continue using information technology, Actual system use: states that the user has used information technology fully based on the benefits obtained

Based on several variables from TAM, a hypothesis can be formulated that will be tested in the study. The research framework and hypotheses describe the relationship between the variables tested in this study including the relationship between the independent variable (Y) the real condition of the system user and the dependent variable (X1) ease of use (X2) usefulness (X3) attitude user (Attitude towards using) and (X4) system user behavior (Behavioral intention of use). The following hypotheses are formulated H1: It is suspected that ease of use affects the actual system use, H2: It is suspected that usefulness affects the actual system use, H3: It is suspected that attitude toward using has an effect on actual system use, H4: It is suspected that behavioral intention of use affects the actual system use

\section{- RESULT AND DISCUSSION}

After obtaining data from 92 respondents and then processing the data, the percentage of male and female sexes was $48.5 \%$ and $51.5 \%$, respectively. Inputting data from the questionnaire results obtained from the results of distributing questionnaires to respondents, namely students who have used or have Blended Learning accounts at the Faculty of Computer Science, Lancang Kuning University. The data is presented with a data recap of each variable. The stages of the TAM test are to test each statement item by making a percentage of the respondents' answers. The results of the recap of respondents' answers are in the following diagram: 


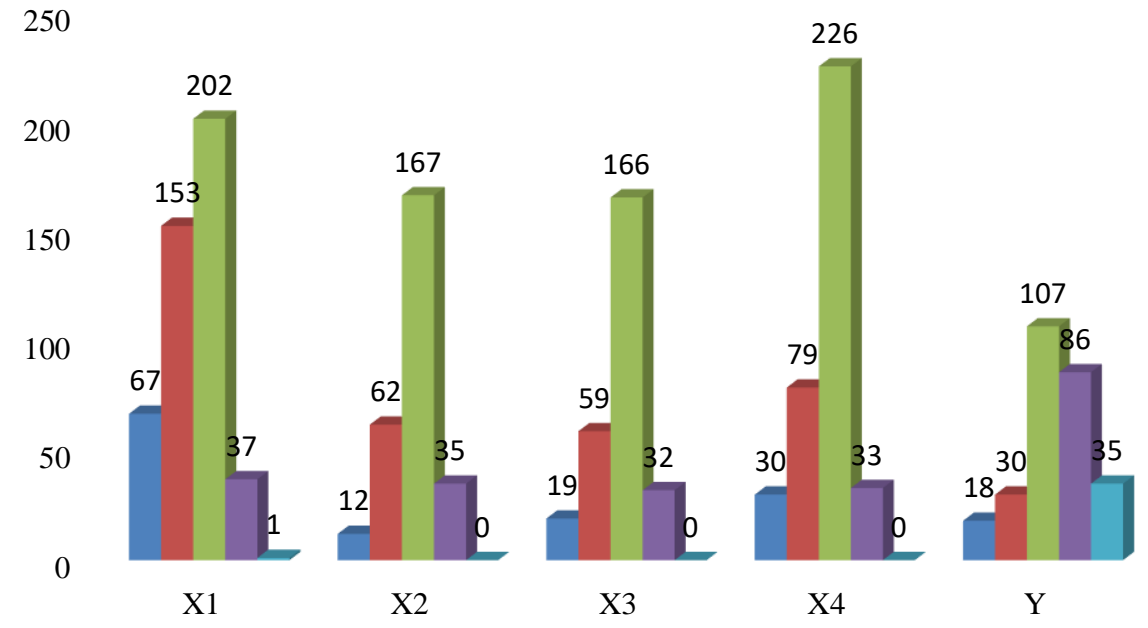

Figure 2. Data recapitulation based on each variable

The diagram above explains the data recap of the results of filling out the questionnaire by the respondents. Questionnaires or questionnaires are divided into four independent variables and one dependent variable. The independent variables include $\mathrm{x} 1, \mathrm{x} 2, \mathrm{x} 3, \mathrm{x} 4$ and for the dependent variable $\mathrm{y}$. The Likert scale was used with five levels, blue to represent strongly agree, orange to agree, neutral gray, yellow to disagree and light to strongly disagree.

Before the data is processed for the purposes of the research phase, the first thing to do is to know the validity and reliability of the data. In the validity test, the questionnaire is declared valid if it is found that the result of $r$ count is greater than $r$ table. It is known that the $r$ table used is 0.173 . The average calculated $r$ value for each instrument of the variable has a value of 0.815 . Based on this value $r$ count is greater than the value of $r$ table, it can be concluded that the validity test is fulfilled for each variable instrument

In addition to the validity test, reliability testing is also required. To conclude the results of the reliability test, taking into account the Cronbach's Alpha value, if the Cronbach's Alpha value $>0.60$ then the questionnaire used can be declared reliable or consistent. On the other hand, if Cronbach's Alpha value is $<0.60$, the questionnaire used can be declared unreliable or inconsistent. The results of reliable calculations for the variable x1 have Cronbach's Alpha values of 0.789, x2: 0.852, x3: 0.859, x4: 0.852. y : 0.852. Of the five variables that have a Cronbach's Alpha value greater than a significant value of 0.60 , then the four variables are declared reliable

Apart from the validity and reliability tests, the classical assumption test also has an equally important role. It aims to provide a basic foundation in the form of something that is certain that the regression equation contains accuracy in terms of estimation, is not classified as biased and is consistent. Normality test intends to ensure the distribution of each variable. The results of the normality test on the variables of use, usefulness, attitude towards use, usage behavior and actual system use have an asim (2-tailed) 0.929 because the asims value is $>0.1$. Thus, the normally distributed variable

The multicollinearity test was carried out with the aim of testing the correlation between the independent (independent) variables. The category used in the multicollinearity test is seen from the Variance Inflation Factor (VIF) value below 10 and 
the tolerance value $>0.10$. It is known that the tolerance values include $0.502,0.286$, $0.342,0.377$ and for the VIF values $1.944,3.496,2.924,2.650$. For the X1 variable heteroscedasticity test it is easy to get the sig value. (2-tailed) of $0.498>0.05$, the benefit variable X2 obtained sig value. (2-tailed) of $0.655>0.05$, the attitude variable X3 obtained a sig value. (2-tailed) of $0.286>0.05$, the behavioral variable $\mathrm{X} 4$ obtained the value of sig. (2-tailed) of $0.200>0.05$ then there is no heteroscedasticity

After going through the stages of the classical assumption test, the researcher then conducted a multiple linear regression test. It aims to determine the relationship between the variables of the TAM method used in the study. The conclusion of the test results using multiple linear regression is a variable that has a significance value $<0.10$. Those that have significant value are the benefits of using the system (perceived usefullness) (X1), attitudes towards using the system (attitude against using) (X3), and behavior to continue using (behavioral intention to use) (X4). While the variable that is not significant is the perception of ease of use (X2). The following is a table of multiple linear regression coefficient values

Determination test is conducted to measure how much the dependent variable can explain the independent variable or show the contribution of all independent variables. Based on the results of the SPSS program, the coefficient of determination adjusted for $\mathrm{R}$ Square is $45.1 \%$. So the four independent variables can explain $45.1 \%$ of the dependent variable only. While $54.9 \%$ is explained by other variables outside the model. Testing for each variable uses the $t$ test to determine the partial (individual) effect of the independent variable. From the test results, it is known that the t-count value of each regression coefficient with the t-table value (critical value) is in accordance with the significance level used. While the t-value of the two independent variables in the real condition of the use of information systems

The t-test (t-test) partially tests the regression coefficients to determine whether the hypothesis is accepted or rejected. By comparing the value of $t$ count with $t$ table. If $t$ count $>\mathrm{t}$ table then $\mathrm{H} 0$ is rejected and $\mathrm{Ha}$ is accepted, then if $\mathrm{t}$ count $<\mathrm{t}$ table then Ho is accepted and $\mathrm{Ha}$ is rejected. Based on the calculation of the accepted hypotheses, $\mathrm{X} 1, \mathrm{X} 2$, $\mathrm{X} 3$ affect the use of information systems. While X4 has no influence on the use of information systems. Simultaneous testing is carried out using the F test. The test is carried out to determine the effect of the independent variables (Use of Information Systems and Ease of Information Systems) simultaneously on the variable Conditions of Use of Information Systems by comparing F count with F table. The variables of ease of use (X1), usefulness (X2), attitude towards use (X3), and usage behavior (X4) have a value of $\mathrm{F}$ arithmetic $>\mathrm{F}$ table or $19.664>1.91$ with a significant value. $0.000<0.05$ thus the hypothesis is accepted simultaneously affects the actual use of the system (Y)

\section{- CONCLUSION}

Based on the measurement results, it is concluded that the unique online learning system or blended-learning can be accepted by students as a solution to access learning information. Based on the hypothesis in this study, there are 3 hypotheses that were declared accepted, namely Easy of use (H1), Useful (H2), Attitude toward using (H3) and one hypothesis was declared rejected, namely Behavioral intention of use (H4). The results of this study indicate that the perception of easy of use, usefulness, and attitude toward using affect the actual system use. This shows that if blended-learning users feel that blended-learning is uniquely easy to use, it will provide benefits for students and affect actual system use. 


\section{- REFERENCES}

Darma, I. K., Karma, I. G. M., \& Santiana, I. M. A. (2020). Blended Learning, Inovasi Strategi Pembelajaran Matematika di Era Revolusi Industri 4.0 Bagi Pendidikan Tinggi[Blended Learning, Mathematics Learning Strategy Innovation in the Industrial Revolution 4.0 Era for Higher Education]. Prosiding Seminar Nasional Pendidikan Matematika, 3, 527-539.

Nerisafitra, P., \& Susanto, F. A. (2019). Analisis Faktor Yang Mempengaruhi Mahasiswa dalam Menggunakan Website Pembelajaran dengan Technology Acceptance Model $(T A M)$ [ Analysis of Factors Affecting Students in Using Learning Websites with Technology Acceptance Model (TAM)]. ... and Educational Technology), 03, 97100. https://journal.unesa.ac.id/index.php/jieet/article/view/6834

Rahayu, F. S., Budiyanto, D., \& Palyama, D. (2017). Analisis Penerimaan E-Learning Menggunakan Technology Acceptance Model (Tam) (Studi Kasus: Universitas Atma Jaya Yogyakarta)[ E-Learning Acceptance Analysis Using the Technology Acceptance Model (Tam) (Case Study: Atma Jaya University Yogyakarta)]. Jurnal Terapan Teknologi Informasi, 1(2), 87-98. https://doi.org/10.21460/jutei.2017.12. 20.

Setiawan, T. H., \& Aden. (2020). Efektifitas Penerapan Blended Learning Dalam Upaya Meningkatkan Kemampuan Akademik Mahasiswa Melalui Jejaring Schoology Di Masa Pandemi Covid-19 [The Effectiveness of Applying Blended Learning in an Effort to Improve Students' Academic Ability Through Schoology Networks During the Covid-19 Pandemic]. Jurnal Pembelajaran Matematika Inovatif (JPMI), 3(5), 493-506. https://doi.org/10.22460/jpmi.v3i5.493-506

Alfian, Ari, N., \& Tjahjadi, D. (2019). Technology Acceptance Model pada Sistem Pembelajaran E-Learning. Information Management for Educators and Professionals [Technology Acceptance Model in E-Learning Learning Systems. Information Management for Educators and Professionals], 4(1), 63-72.

Djusar, S., Sadar, M., \& Asril, E. (2020). Analisa Kualitas Layanan Sistem Smart Unilak Menggunakan Servqual Method [Analysis of Unilak Smart System Service Quality Using Servqual Method]. Digital Zone: Jurnal Teknologi Informasi Dan Komunikasi, 11(2), 278-290.

Fiyah, N., Mayangky, N. A., Hadianti, S., \& Riana, D. (2019). Analisis Technology Acceptance Model Pada Aplikasi Platform Perdagangan Elektronik Di Kalangan Mahasiswa [Analysis of Technology Acceptance Model on Electronic Trading Platform Applications Among Students]. Jurnal Teknik Informatika, 12(1), 59-68.

Flourensia Sapty Rahayu1, Djoko Budiyanto2, D. P. (2017). Analisis Penerimaan ELearning Menggunakan Technology Acceptance Model (Tam) (Studi Kasus: Universitas Atma Jaya Yogyakarta) [ E-Learning Acceptance Analysis Using the Technology Acceptance Model (Tam) (Case Study: Atma Jaya University Yogyakarta)]. Jurnal Terapan Teknologi Informasi, 1(2), 87-98.

Hartatik, S. R., \& Budihartanti, C. (2020). Analisis Kepuasan Pengguna Terhadap Penerapan Aplikasi Go-Jek Dengan Menggunakan Metode TAM ( Technology Acceptance Model )[ Analysis of User Satisfaction on the Implementation of the Go-Jek Application Using the TAM (Technology Acceptance Model) Method]. Jurnal PROSISKO, 7(1), 1-7.

Iqbal, J., \& -, A. (2018). Metode Pembelajaran E-Learning Menggunakan Technology Acceptance Modelling (TAM) Untuk Pembelajaran Akuntansi . InFestasi, 14(2), 116. 
Irawati, T., Rimawati, E., \& Pramesti, N. A. (2020). Penggunaan Metode Technology Acceptance Model ( TAM ) Dalam Analisis Sistem Informasi Alista ( Application Of Logistic And Supply Telkom Akses ). 04(2019), 106-120.

Khairudin, K., Rahmi, E., Rahmidani, R., Rusdinal, R., \& Gistituati, N. (2019). Analisis Kebijakan Penggunaan E-Learning Di Universitas Negeri Padang. Jurnal Ilmu Sosial Dan Humaniora, 8(2), 97.

Tselios, N., Daskalakis, S., \& Papadopoulou, M. (2011). Assessing the acceptance of a blended learning university course. Journal of Educational Technology \& Society, 14(2), 224-235.

Martín-García, A. V., Martínez-Abad, F., \& Reyes-González, D. (2019). TAM and stages of adoption of blended learning in higher education by application of data mining techniques. British Journal of Educational Technology, 50(5), 2484-2500.

Bachtiar, F. A., Rachmadi, A., \& Pradana, F. (2014, February). Acceptance in the deployment of blended learning as a learning resource in information technology and computer science program, Brawijaya university. In 2014 Asia-Pacific Conference on Computer Aided System Engineering (APCASE) (pp. 131-135). IEEE.

Nadlifatin, R., Miraja, B., Persada, S., Belgiawan, P., Redi, A. A. N., \& Lin, S. C. (2020). The measurement of University students' intention to use blended learning system through technology acceptance model (TAM) and theory of planned behavior (TPB) at developed and developing regions: Lessons learned from Taiwan and Indonesia. International Journal of Emerging Technologies in Learning (iJET), 15(9), 219-230.

Yeou, M. (2016). An investigation of students' acceptance of Moodle in a blended learning setting using technology acceptance model. Journal of Educational Technology Systems, 44(3), 300-318.

Tshabalala, M., Ndeya-Ndereya, C., \& van der Merwe, T. (2014). Implementing Blended Learning at a Developing University: Obstacles in the Way. Electronic Journal of Elearning, 12(1), 101-110.

Al-Maroof, R., Al-Qaysi, N., Salloum, S. A., \& Al-Emran, M. (2021). Blended Learning Acceptance: A Systematic Review of Information Systems Models. Technology, Knowledge and Learning, 1-36.

Songsangyos, P., Kankaew, S., \& Jongsawat, N. (2016, July). Learners' acceptance toward blended learning. In 2016 SAI Computing Conference (SAI) (pp. 890-892). IEEE.

Lazar, I. M., Panisoara, G., \& Panisoara, I. O. (2020). Digital technology adoption scale in the blended learning context in higher education: Development, validation and testing of a specific tool. PloS one, 15(7), e0235957.

Olivier, J. (2016). Blended learning in a first-year language class: Evaluating the acceptance of an interactive learning environment. Literator (Potchefstroom. Online), 37(2), 1-12.

Wen, M. H., Chen, C. M., \& Hsu, I. T. (2016). An integrated BIM and cost estimating blended learning model-acceptance differences between experts and novice. Eurasia journal of mathematics, science and technology education, 12(5), 1347-1363.

Yeop, M. A., Yaakob, M. F. M., Wong, K. T., Don, Y., \& Zain, F. M. (2019). Implementation of ICT policy (Blended Learning Approach): Investigating factors of behavioural intention and use behaviour. International Journal of Instruction, 12(1), 767-782. 
Liu, X. (2021). Primary science curriculum student acceptance of blended learning: structural equation modeling and visual analytics. Journal of Computers in Education, 1-27.

Haron, H., Abbas, W. F., \& Abd Rahman, N. A. (2012). The adoption of blended learning among Malaysian academicians. Procedia-Social and Behavioral Sciences, 67, 175181.

Lee, L. T., \& Hung, J. C. (2015). Effects of blended e-Learning: a case study in higher education tax learning setting. Human-centric Computing and Information Sciences, 5(1), 1-15.

Alaidarous, K., \& Madini, A. A. (2016). Exploring EFL students' perception in blended learning environment in Saudi technical education context. International Journal of Educational Investigations, 3(6), 69-81.

Al-Azawei, A., Parslow, P., \& Lundqvist, K. (2017). Investigating the effect of learning styles in a blended e-learning system: An extension of the technology acceptance model (TAM). Australasian Journal of Educational Technology, 33(2).

Wong, K. T., Hamzah, M. S. G., Goh, P. S. C., \& Yeop, M. A. B. (2016). Blended elearning acceptance as smart pedagogical tools: An initial study in Malaysia. Turkish Online Journal of Educational Technology-TOJET, 15(4), 25-31.

Hidayat, M. L., Prasetiyo, W. H., \& Wantoro, J. (2019). Pre-service Student Teachers' Perception of using Google Classroom in A Blended Course. Humanities \& Social Sciences Reviews, 7(2), 363-368.

Sidek, S. F., Yatim, M. H. M., Ariffin, S. A., \& Nurzid, A. (2020). The Acceptance Factors and Effectiveness of MOOC in the Blended Learning of Computer Architecture and Organization Course. Universal Journal of Educational Research, 8(3), 909-915. 